\title{
Tombamento de Mudas Causado por Fusarium solani: uma Nova Doença do Paricá no Brasil
}

\author{
Reginaldo G. Mafia ${ }^{1}$, Acelino C. Alfenas ${ }^{1}$, Gabriela C. G. Andrade ${ }^{1}$, Edival A. V. Zauza ${ }^{1}$, Ludwig H. \\ Pfenning $^{2}$ \& Joilson Rosa ${ }^{3}$
}

\begin{abstract}
${ }^{1}$ Departamento de Fitopatologia, Universidade Federal de Viçosa, CEP 36571-000, Viçosa, MG, e-mail: aalfenas@ufv.br; ${ }^{2}$ Departamento de Fitopatologia, Universidade Federal de Lavras, CEP 37200-000, Lavras, MG; ${ }^{3}$ Floraplac Industrial LTDA., Estrada Colônia do Uraim, Km 01, CEP 68625-970, Paragominas, PA
\end{abstract}

(Aceito para publicação em 27/03/2003)

Autor para correspondência: Acelino C. Alfenas

\section{ABSTRACT}

Damping-off of seedlings caused by Fusarium solani, a new disease of the Paricá in Brazil

Fusarium solani is reported for the first time in Brazil causing damping-off in Schizolobium amazonicum in Paragominas,
PA. Infection starts in the cotiledons, where under conditions of high moisture and temperature they become recovered by a white mycelial mass of fungus with morphological and cultural characteristics typical of F. solani.
Schizolobium amazonicum Huber ex. Ducke, espécie da família botânica Leguminosae (subfamília Caesalpinoideae), conhecida popularmente como Paricá, tem sido utilizada em reflorestamentos para atender a crescente demanda de madeira para produção de chapas de compensados. Registrou-se, em setembro de 2002, a ocorrência de uma nova doença nesta essência florestal na região de Paragominas, PA. A enfermidade caracteriza-se pelo tombamento de mudas (Figura 1A) que se inicia comumente pelos cotilédones (Figura 1B) sob condições de umidade e temperatura elevadas. Com o progresso da doença, os cotilédones tornam-se recobertos por uma massa micelial branca (Figura 1C) de um fungo com características culturais (Figura 1D) e morfológicas (Figura 1 E, Fe G) típicas de Fusarium solani (Mart.) Sacc., incluindo crescimento moderado, clamidósporos rugosos, fiálides longas, finas e solitárias, grande quantidade de microconídios sem septos e poucos macroconídios, além de formação lenta e escassa de esporodóquios (Nelson, P.E., Toussoun, T.A. \& Marasas, W.F. Fusarium species: an illustrated manual for identification. The Pennsylvania State University, 1983). Após o isolamento em cultura pura para BDA, procedeu-se o teste de patogenicidade. Para isso, 25 mudas sadias de Paricá, com 25 dias de idade, foram atomizadas com uma suspensão de inóculo a $2 \times 10^{5}$ conídios/ml e mantidas em câmara de nevoeiro a $27{ }^{\circ} \mathrm{C}$, sob fotoperíodo de $12 \mathrm{~h} /$ dia, até o aparecimento dos sintomas. Além disso, igual número de sementes foi semeada em solo naturalmente infestado e em solo previamente esterilizado e submetido às mesmas condições. Os primeiros sintomas e sinais da doença, nas mudas inoculadas (Figura 1H), surgiram aos sete dias após a emergência das sementes no solo naturalmente infestado com o patógeno. Estes resultados indicam que as infecções, ao nível de viveiro, podem ocorrer durante a germinação da semente, quando os cotilédones entram em contato com o solo (Figura 1I) ou pela água de irrigação contaminada, predominantemente sobre os tecidos de reserva.
O uso de água de irrigação, substrato artificial ou solo isentos de inóculo do patógeno, aliado à eliminação das plantas doentes e o uso de canteiros suspensos constituem alternativas para o controle da doença. A reprodução dos sintomas em todas as mudas sadias inoculadas artificialmente e o reisolamento do fungo para BDA, a partir dos tecidos infetados, confirmou a etiologia da doença.

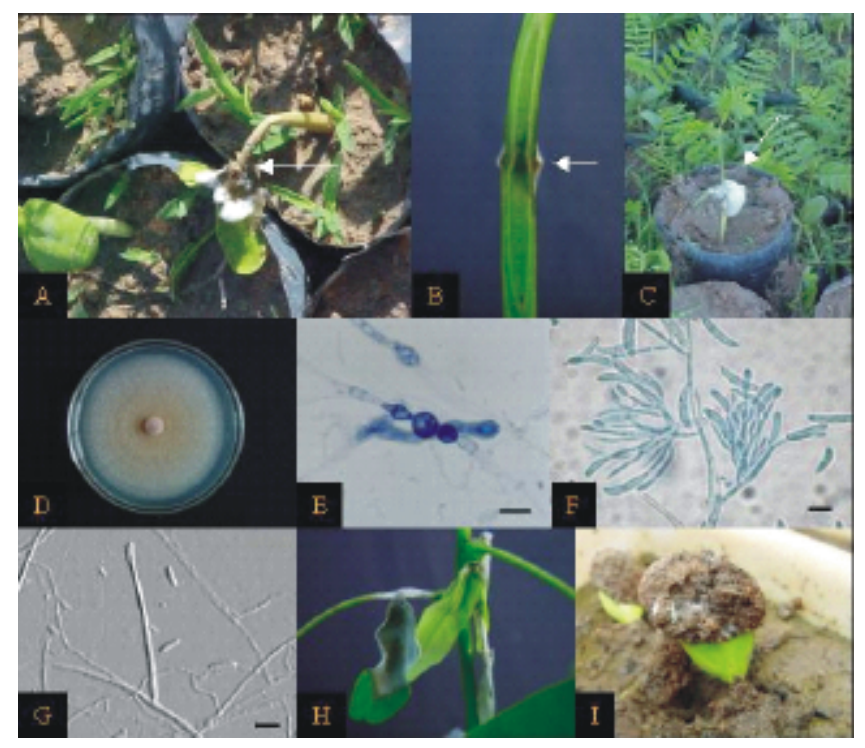

FIG. 1 - Sintomas e sinais do tombamento de mudas de Paricá (Schizolobium amazonicum) e características culturais e morfológicas do seu agente causal, Fusarium solani: (A) tombamento pósemergência; (B) início da enfermidade a partir do ponto de inserção dos cotilédones; $(\mathrm{C})$ cotilédones recobertos por massa micelial branca; (D) colônia típica do fungo em BDA; (E) clamidósporos típicos do patógeno; (F e G) macro e microconídios; $(\mathrm{H})$ sintomas nas mudas inoculadas e (I) emergência de plântulas com solo aderido contendo micélio do patógeno. Barras $=10 \mu \mathrm{m}$. 